\title{
Angka Kejadian Ventilasi Mekanis Berkepanjangan pada Pasien Pasca bedah Pintas Arteri Koroner di RSUP Dr. Hasan Sadikin Bandung Tahun 2014-2016
}

\author{
Reza Widianto Sudjud, Rudi Kurniadi, Esther Hintono \\ Departemen Anestesiologi dan Terapi Intensif \\ Fakultas Kedokteran Universitas Padjadjaran/RSUP Dr. Hasan Sadikin Bandung
}

\begin{abstract}
Abstrak
Bedah Pintas Arteri Koroner adalah salah satu tindakan intervensi untuk mengembalikan perfusi koroner. Pascabedah jantung membutuhkan bantuan ventilasi mekanis yang apabila berkepanjangan akan meningkatkan mortalitas dan morbiditas. Tujuan penelitian ini adalah mengetahui angka kejadian ventilasi mekanis berkepanjangan pascabedah pintas arteri koroner berdasar atas usia, jenis kelamin, fraksi ejeksi ventrikel kiri preoperatif, waktu pintas jantung paru, kadar hemoglobin pascaoperasi, dan komorbiditas pada pasien di RSUP Dr. Hasan Sadikin Bandung tahun 2014-2016. Metode yang digunakan adalah deskriptif observasional dengan pendekatan retrospektif berdasar data rekam medis. Dari hasil penelitian ini diperoleh hasil angka kejadian ventilasi mekanis berkepanjangan adalah 69,7\%. Penelitian ini menunjukkan angka kejadian ventilasi mekanis berkepanjangan pascabedah pintas arteri koroner berdasarkan usia $\leq 65$ tahun adalah $68,1 \%$, usia $>65$ tahun $75,7 \%$, laki-laki $69,1 \%$, perempuan $73,1 \%$, fraksi ejeksi $>50 \%$ sebesar $73,3 \%$, fraksi ejeksi sebesar $66,3 \%$, waktu pintas jantung paru $\leq 90$ menit $47,7 \%$, waktu pintas jantung paru $>90$ menit $81,6 \%$, kadar hemoglobin pascaoperasi $<10 \mathrm{~g} / \mathrm{dL}$ sebesar $75 \%$, kadar hemoglobin $\geq 10 \mathrm{~g} / \mathrm{dL}$ sebesar $66,9 \%$, pasien dengan komorbiditas $69,7 \%$ dan tanpa komorbiditas $69,8 \%$. Sebagai simpulan, didapatkan angka kejadian ventilasi mekanis berkepanjangan lebih tinggi pada pasien usia $>65$ tahun, pasien perempuan, pasien dengan fraksi ejeksi $\leq 50 \%$, waktu pintas jantung paru $>90$ menit dan kadar $\mathrm{Hb}$ pascaoperasi $<10 \mathrm{~g} / \mathrm{dL}$
\end{abstract}

Kata kunci: Bedah pintas arteri koroner, faktor risiko, ventilasi mekanis berkepanjangan

\section{Incidence Rates of Prolonged Mechanical Ventilation in Patients Post Coronary Arterial Bypass Grafting at Dr. Hasan Sadikin General Hospital Bandung in 2014-2016}

\begin{abstract}
Coronary Artery Bypass Grafting (CABG) is an intervention to restore coronary perfusions. Postcardiac surgery requires mechanical ventilation, which, if prolonged, will increase morbidity and mortality.The purpose of this study was to determine the incidence of prolonged mechanical ventilation post-CABG based on age, sex, preoperative left ventricular ejection fraction (LVEF), cardio pulmonary bypass (CPB) time, postoperative hemoglobin levels, and patient comorbidity at Dr. Hasan Sadikin General Hospital Bandung in 2014-2016. The method used in this study was an observational descriptive retrospective approach based on medical records. The results of this study showed the incidence of prolonged mechanical ventilation incidence was $69.7 \%$. This study showed that incidence of post-CABG prolonged mechanical ventilation based on age $\leq 65$ years old were $68.1 \%$, age $>65$ years old were $75.7 \%$, men were $69.1 \%$, women were $73.1 \%$, LVEF $\leq 50 \%$ were $73.3 \%$, LVEF $>50 \%$ were $66.3 \%$, CPB time $<90$ minutes were $47.5 \%$, CPB time $>90$ minutes were $81.6 \%$, postoperative hemoglobin level $<10 \mathrm{~g} / \mathrm{dL}$ were $75 \%$, hemoglobin level $\geq 10 \mathrm{~g} / \mathrm{dL}$ were $66.9 \%$, patients with comorbidities were $69.7 \%$ and without comorbidities were $69.8 \%$. In conclusion, there was higher incidence of prolonged mechanical ventilation in patients $>65$ years old, woman, with $\mathrm{LVEF} \leq 50 \%$, CPB time $>90$ minutes and postoperative hemoglobin level $<10 \mathrm{~g} / \mathrm{dL}$.
\end{abstract}

Key Words: Coronary artery bypass grafting, prolonged mechanical, risk factor

Korespondensi: Dr. Reza Widianto Sudjud, dr. SpAn-KAKV, KIC. M. Kes, Departemen Anestesiologi dan Terapi Intensif Fakultas Kedokteran Universitas Padajdjaran/Rumah Sakit Dr. Hasan Sadikin Bandung, Jl. Pasteur No 38 Bandung 40161, Tlpn 022-2038285, Email rezasudjud@yahoo.com 


\section{Pendahuluan}

Penyakit jantung merupakan salah satu masalah kesehatan dunia yang berhubungan dengan bertambahnya usia penduduk. Penyakit jantung diperkirakan akan terus meningkat selama beberapa dekade mendatang. Jumlah orang yang berusia $\geq 60$ tahun diperkirakan menjadi dua kali lipat pada tahun 2025 dan menjadi tiga kali lipat pada tahun 2050. Pada tahun 2009, kematian yang disebabkan oleh penyakit kardiovaskular di Asia Pasifik sebesar 33,4\% dan angka ini lebih besar dibanding dengan kematian karena kanker, trauma dan kecelakaan, penyakit diabetes melitus (DM) dan penyakit paru-paru. Kematian akibat penyakit kardiovaskular pada tahun 2009 di Asia Afrika berjumlah 16.429, sedangkan kematian akibat penyakit jantung koroner (PJK) berjumlah 7.752 dan kematian karena infark miokard sebesar 2.462. Intervensi klinis untuk mengembalikan perfusi miokardium yang iskemik adalah trombolisis, angioplasti koroner perkutan dan/atau bedah pintas arteri koroner. ${ }^{1-3}$

Bedah pintas arteri koroner adalah tindakan bedah jantung yang paling sering dilakukan di Amerika Serikat. Teknik bedah dan anestesi berkembang dengan baik sehingga keberhasilan bedah pintas arteri koroner sering ditentukan dari kemampuan untuk bertahan pada masa pascaoperasi. Penggunaan ventilasi mekanis pascabedah pintas arteri koroner yang lama berhubungan dengan meningkatnya kejadian morbiditas dan mortalitas sehingga lama rawat ruang intensif dan biaya perawatan juga meningkat. ${ }^{4,5}$

Ekstubasi dini (dalam waktu 8-12 jam setelah sampai ruang intensif) harus menjadi gold standard karena berhubungan dengan perbaikan fungsi jantung, kenyamanan pasien, komplikasi pernapasan, lama rawat dan biaya rawat ruang intensive care unit (ICU). Ventilasi mekanis berkepanjangan pada pasien risiko tinggi harus diidentifikasi dari awal sebelum dilakukan bedah pintas arteri koroner. Kegagalan penyapihan ventilasi mekanis dan ektubasi berhubungan dengan beberapa faktor yang dikelompokkan menjadi faktor preoperatif, intraoperatif dan pascaoperatif. ${ }^{6}$

Faktor preoperatif yang berpengaruh terhadap penggunaan ventilasi mekanis pascabedah jantung diantaranya adalah indeks masa tubuh besar, diabetes melitus, peningkatan tekanan arteri pulmoner, hipoalbumin, usia tua, dan rendahnya fraksi ejeksi ventrikel kiri. Faktor intraoperatif yang mempengaruhi lama bantuan ventilasi mekanis diantaranya waktu pintas jantung paru, cross clamping time, jumlah transfusi intraoperatif, lama operasi, dan perdarahan. Faktor pascaoperasi yang dapat berpengaruh terhadap lama bantuan ventilasi mekanis adalah hematokrit rendah dan perbandingan $\mathrm{PaO}_{2} / \mathrm{FiO}_{2}$ rendah. Pasien dengan $\mathrm{PJK}$ sering mempunyai satu atau lebih komorbiditas, seperti hipertensi, diabetes melitus (DM), penyakit vaskular perifer, penyakit serebrovaskular, disfungsi ginjal, dan gagal jantung kelas II atau lebih menurut New York Heart Association (NYHA). ${ }^{5-6}$

Saat ini belum ada data jumlah pasien pascabedah pintas arteri koroner dengan ventilasi mekanis berkepanjangan di RSUP Dr. Hasan Sadikin Bandung dilihat dari beberapa faktor. Tujuan penelitian ini adalah mengetahui angka kejadian ventilasi mekanis berkepanjangan pascabedah pintas arteri koroner berdasarkan usia, jenis kelamin, fraksi ejeksi ventrikel kiri preoperatif, waktu pintas jantung paru, kadar hemoglobin ( $\mathrm{Hb})$ pascaoperasi, dan komorbiditas pasien. Hasil penelitian ini diharapkan dapat menjadi pertimbangan dalam proses penyapihan ventilasi mekanis pasien pasacabedah pintas arteri koroner sehingga morbiditas, mortalitas, komplikasi dan lama rawat dapat diminimalkan.

\section{Subjek dan Metode}

Penelitian ini merupakan deskriptif observasional. Data penelitian diperoleh dari rekam medis pasien yang menjalani bedah pintas arteri koroner dan dirawat di ICU jantung RSUP Dr. Hasan Sadikin Bandung pada periode Januari 2014 sampai Desember 2016. Pasien dengan data rekam medis yang 
tidak lengkap dan menjalani bedah pintas arteri koroner disertai operasi katup jantung dikeluarkan dari penelitian.

Penelitian ini telah mendapatkan persetujuan dari Komite Etik Penelitian Kesehatan Fakultas Kedokteran Universitas Padjadjaran No: LB.02.01/X.6.5/357/2018. Data penelitian yang diambil adalah usia, jenis kelamin, fraksi ejeksi ventrikel kiri preoperatif, waktu pintas jantung paru, kadar $\mathrm{Hb}$ pascaoperasi, komorbiditas pasien dan lama ventilasi mekanis. Pada penelitian ini, pasien dengan komorbiditas adalah pasien yang mempunyai satu atau lebih dari 3 penyakit yaitu hipertensi, Diabetes melitus, dan gangguan fungsi ginjal, sedangkan pasien yang termasuk dalam kelompok ventilasi mekanis berkepanjangan adalah pasien pascabedah jatung dengan lama ventilasi mekanis $>12$ jam. Data hasil penelitian dianalisis kemudian dideskripsikan menggunakan persentase sesuai dengan variabel yang diidentifikasi selama penelitian.

\section{Hasil}

Karakteristik pasien yang termasuk dalam subjek penelitian (175 pasien) didapatkan bahwa jumlah pasien dengan usia $\leq 65$ tahun dan pasien laki-laki lebih banyak $(78,9 \%$ dan $85,1 \%$ ). Jumlah pasien dengan fraksi ejeksi preoperatif $>50 \%$ dan jumlah pasien dengan fraksi ejeksi preoperatif $\leq 50 \%$ hampir sama, yaitu 50,9\% dan 49,1\%. Pada penelitian ini, pasien yang selama operasi memiliki waktu pintas jantung paru $>90$ menit lebih banyak $(65,1 \%)$ dan pasien dengan kadar $\mathrm{Hb}$ pasacoperasi $\geq 10 \mathrm{~g} / \mathrm{dL}$ lebih banyak $(65,7 \%)$. Sebanyak 132 pasien $(75,4 \%)$ pasien yang menjalani bedah pintas arteri koroner mempunyai komorbiditas (Tabel 1).

Ventilasi mekanis berkepanjangan terjadi pada 122 pasien dengan angka kejadian 69,7\%. Angka kejadian ventilasi mekanis berkepanjangan pada pasien dengan usia $>65$ tahun lebih tinggi $(75,7 \%)$ dibandingkan pasien dengan usia $\leq 65$ tahun. Pasien perempuan cenderung membutuhkan ventilasi mekanis lebih lama dengan angka kejadian ventilasi
Tabel 1 Karakteristik Subjek Penelitian

\begin{tabular}{|c|c|}
\hline Variabel & $\begin{array}{c}f(\%) \\
(n=175)\end{array}$ \\
\hline \multicolumn{2}{|l|}{ Usia (tahun) } \\
\hline$\leq 65$ & $138(78,9 \%)$ \\
\hline$>65$ & $37(21,1 \%)$ \\
\hline \multicolumn{2}{|l|}{ Jenis kelamin } \\
\hline Laki-laki & $149(85,1 \%)$ \\
\hline Perempuan & $26(14,9 \%)$ \\
\hline \multicolumn{2}{|c|}{ Fraksi ejeksi preoperatif (\%) } \\
\hline$>50$ & $89(50,9 \%)$ \\
\hline$\leq 50$ & $86(49,1 \%)$ \\
\hline \multicolumn{2}{|c|}{$\begin{array}{l}\text { Waktu pintas jantung paru } \\
\text { (menit) }\end{array}$} \\
\hline$\leq 90$ & $61(34,9 \%)$ \\
\hline$>90$ & $114(65,1 \%)$ \\
\hline \multicolumn{2}{|c|}{ Kadar Hb pascaoperasi (g/dL) } \\
\hline$<10$ & $60(34,3 \%)$ \\
\hline$\geq 10$ & $115(65,7 \%)$ \\
\hline \multicolumn{2}{|c|}{ Komorbiditas pasien } \\
\hline Ya & $132(75,4 \%)$ \\
\hline Tidak & $43(24,6 \%)$ \\
\hline Keterangan : & $\begin{array}{l}\text { disajikan dengar } \\
\text { persentase } \\
\text { rik disajikan } \\
\text {, standar devias }\end{array}$ \\
\hline
\end{tabular}

mekanis berkepanjangan 73,1\%.Pasien dengan fraksi ejeksi preoperatif $\leq 50 \%$ menunjukkan angka kejadian lebih tinggi yaitu 73,3\%. Pasien dengan waktu pintas jantung paru $>90$ menit mempunyai angka kejadian ventilasi mekanis berkepanjangan lebih tinggi $(81,6 \%)$. Angka kejadian ventilasi mekanis berkepanjangan pada pasien dengan kadar $\mathrm{Hb}$ pascaoperatif $<10 \mathrm{~g} / \mathrm{dL}$ lebih tinggi (75\%). Angka kejadian ventilasi mekanis berkepanjangan pada pasien dengan komorbiditas dan tanpa komorbiditas mempunyai angka hampir sama, yaitu 69,7\% dan 69,8\% (Tabel 2).

\section{Pembahasan}

Pada penelitian ini didapatkan $78,9 \%$ pasien pada usia $\leq 65$ tahun yang menggambarkan 
Tabel 2 Angka Kejadian Ventilasi Mekanis Berkepanjangan Berdasar atas Karakteristik Pasien

\begin{tabular}{lccc}
\hline \multicolumn{1}{c}{ Karakteristik Pasien } & $\mathbf{n}$ & \multicolumn{2}{c}{ Ventilasi Mekanis Berkepanjangan } \\
\cline { 3 - 4 } & & $f$ & Angka Kejadian (\%) \\
\hline Umum (total) & 175 & 122 & 69,7 \\
Usia (tahun) & & & \\
$\quad \leq 65$ & 138 & 94 & 68,1 \\
$\quad>65$ & 37 & 28 & 75,7 \\
Jenis kelamin & & & \\
$\quad$ Laki-laki & 149 & 103 & 69,1 \\
$\quad$ Perempuan & 26 & 19 & 73,1 \\
Fraksi ejeksi preoperatif (\%) & & & \\
$\quad>50$ & 89 & 59 & 66,3 \\
$\quad \leq 50$ & 86 & 63 & 73,3 \\
Waktu pintas jantung paru (menit) & & & 47,5 \\
$\quad \leq 90$ & 61 & 29 & 81,6 \\
$\quad>90$ & 114 & 93 & 75 \\
Kadar Hb pascatoperatif (g/dL) & & & 66,9 \\
$\quad<10$ & 60 & 45 & 69,7 \\
$\quad \geq 10$ & 115 & 77 & 69,8 \\
Komorbiditas pasien & & & \\
$\quad$ Ya & 132 & 92 & \\
$\quad$ Tidak & 43 & 30 & \\
\hline
\end{tabular}

Keterangan: Untuk data kategorik disajikan dengan jumlah/frekuensi dan persentase sedangkan data numerik disajikan dengan rerata, median, standar deviasi dan range

bahwa terjadi pergeseran usia pasien yang menderita PJK dan membutuhkan intervensi klinis yaitu pada kelompok usia yang lebih muda. Hal ini mungkin disebabkan oleh perubahan gaya hidup yang kurang sehat, baik dari aktivitas fisik dan pola makan. Sebesar $85,1 \%$ pasien adalah laki-laki, hal ini mungkin disebabkan oleh kebiasaan merokok yang merupakan faktor predisposisi PJK lebih banyak ditemukan pada laki-laki. Selain itu, pada wanita ditemukan kadar hormon estrogen lebih tinggi dibanding dengan lakilaki, sehingga terjadinya aterosklerosis pada perempuan lebih lambat. Persentase pasien dengan fraksi ejeksi ventrikel kiri preoperatif $\leq 50 \%$ mempunyai nilai hampir sama dengan fraksi ejeksi $>50 \%$ yaitu $49,1 \%$ dan $50,9 \%$. Usia tua juga berpengaruh terhadap fungsi jantung pasien bahwa terjadi penurunan fungsi jantung akibat proses penuaan. Besarnya fraksi ejeksi ventrikel kiri preoperatif juga ditentukan oleh seberapa luas iskemik yang terjadi sehingga memengaruhi kontraktilitas jantung.

Hasil penelitian ini juga menunjukkan $65,1 \%$ pasien mempunyai waktu pintas jantung paru $>90$ menit. Lama pintas jantung paru selama tindakan bedah jantung akan memengaruhi luaran pasien dalam masa perawatan pascaoperasi, semakin lama pintas jantung paru maka luaran pasien pascabedah jantung semakin buruk karena proses inflamasi akibat mesin pintas jantung paru dan reperfussion injury. Lama pintas jantung $>90$ menit dapat disebabkan oleh berbagai macam faktor, antar lain kompleksitas prosedur bedah, keberhasilan penyapihan fungsi jantung dari mesin pintas jantung paru menjadi, dan juga keterampilan operator bedah.

Hemoglobin berfungsi dalam hal hantaran oksigen (oxygen delivery). Target kadar $\mathrm{Hb}$ pascabedah adalah $\geq 10 \mathrm{~g} / \mathrm{dL}$ dengan harapan kebutuhan oksigen untuk kerja otot pernapasan saat pasien mulai bernapas spontan tercukupi sehingga penyapihan 
ventilasi mekanis pascabedah jantung berhasil dilakukan dengan cepat. Pada penelitian ini ditemukan sebesar $34,3 \%$ pasien mempunyai kadar $\mathrm{Hb}$ pascaoperasi $<10 \mathrm{~g} / \mathrm{dL}$. Hal ini mungkin disebabkan oleh perdarahan yang banyak selama durante operasi. Pasien PJK biasanya mempunyai komorbiditas yang mungkin merupakan predisposisi terjadinya aterosklerosis. Pada penilitian ini, terdapat $24,6 \%$ pasien tanpa disertai komorbiditas. Hal ini mungkin disebabkan peneliti yang hanya mengambil data 3 penyakit (hipertensi, DM, dan disfungsi ginjal) yang terdokumentasi dalam status rekam medis.

Pada hasil penelitian ini, didapatkan 122 pasien dengan angka kejkadian 69,7\% termasuk dalam kelompok ventilasi mekanis berkepanjangan atau dengan kata lain mendapatkan bantuan ventilasi mekanis berkepanjangan $>12$ jam. Dari hasil ini dapat dilihat bahwa pasien pascabedah jantung cenderung mengalami ventilasi mekanis berkepanjangan sehingga kemungkinan morbiditas, mortalitias, lama rawat dan biaya rawat juga meningkat. Pemilihan 12 jam sendiri didasarkan pada pola atau rutinitas bedah jantung yang ada di RSUP Dr. Hasan Sadikin Bandung bahwa pasien pascabedah jantung selesai lebih kurang pukul 16.00. Tindakan penyapihan ventilasi mekanis dilakukan apabila efek anestesi pada pasien mulai hilang, hasil laboratorium darah baik, dan hemodinamik pasien stabil. Oleh karena itu, tindakan penyapihan ventilasi mekanis baru dilakukan saat keesokan harinya.

Pada kategori usia, hasil penelitian ini menunjukkan angka kejadian ventilasi mekanis berkepanjangan pada usia $>65$ tahun lebih besar yaitu 75,1\%, sedangkan pada usia $\leq 65$ tahun sebesar $68,1 \%$. Usia tua memengaruhi penggunaan ventilasi mekanis pascabedah pintas arteri koroner sehubungan dengan komorbiditas yang biasanya menyertai pasien usia tua, seperti disfungsi ventrikel kiri, DM, penyakit paru obstruktif kronis (PPOK), gangguan fungsi ginjal, dan penyakit arteri perifer. Selain itu, pasien usia tua juga mengalami perubahan pada sistem pernapasan dan kardiovaskular akibat proses penuaan. $^{7}$

Perubahan yang terjadi adalah perubahan rongga dada yang mengganggu compliance paru sehingga meningkatkan usaha pernapasan. Parenkim paru-paru kehilangan struktur pendukungnya dan menyebabkan senile emphysema. Kekuatan otot pernapasan juga menurun dan mengganggu efektivitas batuk yang penting untuk pembersihan jalan napas. Pada usia tua juga terjadi peningkatan alveolar dead space sehingga mempengaruhi oksigen arteri tanpa mengganggu eliminasi karbon dioksida. Pada usia tua terjadi penurunan respons sesak dan ventilasi terhadap hipoksia dan hiperkapnia, sehingga lebih rentan terhadap kejadian gagal napas, terutama dalam konndisi oxygen demand tinggi, seperti gagal jantung, dan pneumonia. ${ }^{8}$

Perubahan yang terjadi pada pembuluh darah kecil dan besar jantung akibat proses penuaan dapat menurunkan cadangan fisiologis seseorang. Kebanyakan pasien tidak menunjukkan tanda-tanda gangguan hemodinamik saat istirahat, tetapi stress akibat operasi dan anestesi akan mengganggu cadangan kardiovaskular. Lapisan tunika intima pembuluh darah menjadi lebih kasar seiring dengan bertambahnya usia. Selain itu pada pasien usia tua terjadi kekakuan dinding pembuluh darah sehingga meningkatkan resistensi pembuluh darah perifer yang mengakibatkan peningkatan tekanan diastole. Peningkatan afterload yang terus menerus menyebabkan perubahan myocyte yang lebih cepat melalui proses apoptosis diikuti hipertrofi sel-sel yang tersisa sehingga terjadi fibrosis interstitial. Maka ventrikel menjadi hipertrofi dan pengembangan otot jantung saat berkontraksi terbatas sehingga terjadi disfungsi diastole. Pengisian diastole awal pada usia lebih dari 80 tahun berkurang sepertiga sampai setengah jika dibanding dengan usia 20 tahun. Peningkatan afterload dan disfungsi diastole dapat menyebabkan gagal jantung kongestif dan edema paru sehingga terjadi kegagalan penyapihan ventilasi mekanis. ${ }^{7}$

Dari hasil penelitian dapat dilihat angka kejadian ventilasi mekanis berkepanjangan pada pasien perempuan lebih tinggi dibanding 
dengan pasien laki-laki, yaitu 73,1\% dibanding 69,1\%.Luaspermukaantubuh padaperempuan lebih kecil sehingga diameter pembuluh darah koroner juga lebih kecil. Saat terbentuk plak koroner pada pembuluh darah koroner yang kecil pada perempuan akan menyebabkan penyempitan koroner lebih hebat dibanding laki-laki dengan ukuran plak yang sama. Faktor lain yang berhubungan degan jenis kelamin perempuan yaitu lebih sedikitnya graft yang digunakan, arteri mammary internal yang lebih jarang digunakan, lebih rendahnya hematokrit preoperatif. Hal ini berhubungan dengan patensi graft pembuluh darah yang dapat mengakibatkan gagal jantung pascaoperatif. Luas permukaan tubuh yang kecil pada perempuan merupakan faktor risiko terjadinya low cardiac output syndrome.

Kondisi gagal jantung atau kondisi low cardiac output syndrome dapat menyebabkan edema paru sehingga pasien harus mendapatkan ventilasi mekanis berkepanjangan. Penyebab lain angka kejadian ventilasi mekanis berkepanjangan pada perempuan lebih tinggi karena perempuan lebih sering menunjukkan gejala penyakut jantung koroner di usia tua (karena berhubungan dengan penurunan kadar hormon estrogen yang dikatakan dapat memperlambat aterosklerosis) sehingga kondisi komorbiditas pasien lebih sering ditemukan. ${ }^{9}$

Pada penelitian dipilih batas fraksi ejeksi ventrikel kiri preoperatif sebesar 50\% karena rata-rata pasien yang menjalani bedah pintas arteri koroner di RSUP Dr. Hasan Sadikin Bandung pada tahun 2014-2016 mempunyai nilai fraksi ejeksi preoperatif $>40 \%$. Pada beberapa jurnal, batas fraksi ejeksi adalah 40\%, bahkan 30\%. Hasil penelitian ini menunjukkan angka kejadian ventilasi mekanis berkepanjangan pada pasien dengan fraksi ejeksi $\leq 50 \%$ lebih tinggi dibanding dengan pasien dengan fraksi ejeksi $>50 \% \quad(73,3 \%$ dibanding $66,5 \%)$. Fraksi ejeksi preoperatif rendah mempunyai risiko komplikasi pernapasan lebih tinggi dibandingkan dengan pasien dengan fraksi ejeksi normal. ${ }^{4}$ Perubahan fraksi ejeksi mungkin tidak mencerminkan kontraktilitas tetapi mencerminkan proses remodeling yang terjadi. Remodeling adalah istilah yang digunakan untuk menggambarkan perubahan struktur otot jantung setelah kejadian infark otot jantung luas. Jaringan parut dan penipisan otot jantung yang mengalami infark disertai fibrosis interstitial otot jantung sehat meningkatkan volume akhir diastole. Proses remodeling akan menyebabkan berkurangnya kemampuan kontraktilitas miosit sehingga terjadi disfungsi diastolik pascaoperasi yang dapat menyebabkan keterlambatan ekstubasi karena kemungkinan terjadi gagal jantung kongestif. ${ }^{10-11}$

Angka kejadian ventilasi mekanis berkepanjangan pada pasien dengan waktu pintas jantung paru $\leq 90$ menit lebih kecil dibanding dengan pasien dengan waktu pintas jantung paru $>90$ menit $(47,5 \%$ dibanding $81,6 \%)$. Mesin pintas jantung paru memiliki efek samping terhadap beberapa sistem tubuh pasien, yaitu jantung, paru, ginjal dan otak. Disfungsi paru adalah salah satu komplikasi paling awal yang dapat diketahui dari tindakan bedah jantung menggunakan mesin pintas jantung paru. Beberapa penelitian mengatakan terjadi perubahan (eslastisitas atau compliance atau resistensi) akibat mesin pintas jantung paru dan terjadi perubahan permeabilitas kapiler paru-paru.

Ketidakseimbangan pertukaran gas yang terjadi diduga disebabkan oleh atelektasis dan berkurangnya volume paru secara bersamaan. Penyebab disfungsi paru-paru dan Acute Respiratory Distress Syndrome (ARDS) pascabedah jantung adalah kompleks tetapi sebagian besar diduga akibat respons inflamasi sistemik akibat penggunaan mesin pintas jantung paru dan peningkatan permeabilitas endotel paru. Penyebab sebenarnya adalah terjadinya inflamasi hebat yang terjadi akibat interaksi antara darah dengan permukaan selang mesin pintas jantung paru atau inflamasi akibat terjadinya hipoperfusi splanknik yang menyebabkan terjadinya perpindahan sejumlah besar endotoksin ke dalam pembuluh darah. Endotoksin adalah mediator proinflamasi yang mempunyai efek 
langsung terhadap pembuluh vaskular paruparu. Penelitian yang dilakukan sebelumnya menunjukkan peningkatan molekul adhesi intrasel yang bersirkulasi dalam darah pada pasien dengan acute lung injury pascabedah jantung dengan mesin pintas jantung paru. ${ }^{12-13}$

Fungsi paru dipengaruhi oleh efek kaskade inflamasi yang terjadi akibat penggunaan mesin pintas jantung paru. Proses inflamasi ini memproduksi mediator inflamasi, radikal bebas, protease, leukotriene, asam arakidonat. Peningkatan pelepasan mediator inflamasi yang terjadi selama penggunaan mesin pintas jantung paru menyebabkan peningkatan permeabilitas paru dan terjadi akumulasi protein dan sel inflamasi pada jaringan interstitial sehingga akhirnya dapat menyebabkan mikroatelektasis, peningkatan shunt paru-paru, produksi surfactant menurun, compliance menurun dan resitensi paru meningkat. Semua hal ini menyebabkan peningkatan beban paru pascaoperasi. ${ }^{14}$

Angka kejadian ventilasi mekanis berkepanjangan pada pasien dengan kadar $\mathrm{Hb}$ postoperartif $<10 \mathrm{~g} / \mathrm{dL}$ lebih besar dibanding dengan pasien dengan kadar $\mathrm{Hb}$ postoperatif $\geq 10 \mathrm{~g} / \mathrm{dL}$ (75\% dibanding 66,9\%). Angka kejadian ventilasi mekanis berkepanjangan lebih besar pada pasien dengan kadar $\mathrm{Hb}$ postoperatif $<10 \mathrm{~g} / \mathrm{dL}$ berhubungan dengan fungsi $\mathrm{Hb}$ dalam hantaran oksigen (oxygen delivery). Hemoglobin adalah protein sel darah merah yang memungkinkan darah mengangkut oksigen. Oksigen dari atmosfer harus ditransportasikan secara efektif ke dalam sel sehingga metabolisme berjalan normal. Anemia, kadar hemoglobin kurang dari normal, dapat menyebabkan hantaran oksigen ke jaringan tubuh berkurang dan keadaan ini disebut hipoksia anemia. Pasien sakit kritis, pasien usia tua dan pasien dengan PJK biasanya lebih tidak dapat menoleransi keadaan anemia. Selama proses penyapihan ventilasi mekanis, keadaan anemia memengaruhi hantaran oksigen sedangkan ventrikel kiri tidak dapat meningkatkan curah jantung untuk mencukupi kebutuhan oksigen akibat kerja otot pernapasan yang mulai bernapas spontan. ${ }^{15-17}$
Penelitian di China tahun 2010, mengatakan kadar $\mathrm{Hb}$ rendah pascaoperasi merupakan salah satu faktor risiko terjadinya ventilasi mekanis berkepanjangan, selain usia, waktu pintas jantung paru, penggunaan Intra Aortic Balloon Pump dan rendahnya $\mathrm{PaO}_{2}$ preoperatif. ${ }^{18}$ Penelitian serupa di China tahun 2012 menyebutkan bahwa anemia pascaoperasi merupakan faktor risiko terjadinya ventilasi mekanis berkepanjangan selain kondisi gagal jantung kongestif preoperatif, hipoalbumin preoperatif, dan rendahnya $\mathrm{PaO}_{2}$ preoperatif. ${ }^{19}$ Penelitian tahun 2015 di Inggris, menyebutkan hematokrit rendah, penggunaan inotropik dan kadar $\mathrm{PaO}_{2}$ pascabedah merupakan faktor-faktor risiko lamanya bantuan ventilasi mekanis. ${ }^{20}$

Pada penelitian ini pasien dikatakan mempunyai komorbiditas apabila mempunyai satu atau lebih penyakit hipertensi, DM, dan disfungsi ginjal (ditandai dengan peningkatan serum kreatinin). Hasil penelitian menunjukkan angka kejadian ventilasi mekanis berkepanjangan pada pasien dengan komorbiditas sebesar $69,7 \%$ dan pada pasien tanpa komorbiditas sebesar 69,8\%. Persentase pasien dengan komorbiditas pada kedua kelompok pasien menunjukkan angka hampir sama. Pasien dengan PJK yang akan menjalani tindakan bedah jantung biasanya mempunyai satu atau lebih komorbiditas, antara lain hipertensi, DM, penyakit vaskular perifer, penyakit otak-pembuluh darah, gagal fungsi ginjal, rendahnya fraksi ejeksi ventrikel kiri dan gagal jantung kelas II atau lebih menurut klasifikasi NYHA. Beberapa dari komorbiditas ini dapat berhubungan dengan kejadian ventilasi mekanis berkepanjangan atau kejadian intubasi ulang pascabedah pintas arteri koroner. ${ }^{5}$

Peneliti mengambil 3 penyakit yang paling sering menyertai pasien PJK, yaitu DM, hipertensi dan CKD. Diabetes melitus merupakan salah satu kelainan sistem endokrin yang berpengaruh terhadap kejadian morbiditas dan mortalitas pascabedah pintas arteri koroner, terutama apabila kadar gula pasien tidak terkontrol dengan baik. Peningkatan kadar ureum atau serum 
kreatinin sebelum operasi juga merupakan faktor risiko yang meningkatkan peluang terjadinya komplikasi respirasi pascabedah. Sedangkan penyakit hipertensi dikatakan merupakan faktor pasti yang berhubungan dengan komplikasi respirasi pascaoperasi. ${ }^{21}$

Pada penelitian ini, didapatkan tidak ada pengaruh komorbiditas pasien terhadap kejadian ventilasi mekanis berkepanjangan mungkin karena semua komorbiditas yang didokumentasikan hanya DM, hipertensi dan disfungsi ginjal. Angka kejadian ventilasi mekanis berkepanjangan menunjukan hasil yang hampir sama mungkin juga dikarenakan padapasientanpakomorbiditas, terdapatfaktor lain yang lebih berpengaruh terhadap kondisi hemodinamik pasien saat proses penyapihan sehingga pasien tidak mungkin dilakukan penyapihan ventilator dengan cepat, sehingga diperlukan penelitian yang melihat hubungan antar faktor risiko penyebab kejadian ventilasi mekanis berkepanjangan pascabedah jantung termasuk faktor komorbiditas pasien.

\section{Simpulan}

Angka kejadian ventilasi mekanis berkepanjangan pada pasien pascabedah pintas arteri koroner di RSUP Dr. Hasan Sadikin tahun 2014-2016 adalah 69,7\%, dan angka kejadian ventilasi mekanis berkepanjangan lebih tinggi pada pasien usia $>65$ tahun $(75,7 \%)$, perempuan $(73,1 \%)$, fraksi ejeksi ventrikel kiri preoperatif $£ 50 \%(73,3 \%)$, lama pintas jantung $>90$ menit $(81,6 \%)$, dan kadar $\mathrm{Hb}$ pascaoperatif $<10 \mathrm{~g} / \mathrm{dL}(75 \%)$.

\section{Daftar Pustaka}

1. Sasayama S. Heart disease in asia. Circulation. 2008;118:2669-71.

2. American Heart Association. Asian \& Pacific Islanders and cardiovascular disease. Statistical Fact Sheet 2013 Update. 2013.

3. Suleiman MS, Zacharowski K, Angelini GD. Inflammatory response and cardioprotection during open-heart surgery: the importance of anaesthetics. Br J Pharmacol. 2008;153:21-33.
4. Spivack SD, Shinozaki T, Albertini JJ, Deane R. Preoperative prediction of postoperative respiratory outcome. CHEST. 1996;109:1222-30.

5. Flegler S, Paro FM. Factors associated with intubation time and ICU stay after CABG. Braz J Cardiovasc Surg. 2015;30(6):631-5.

6. CislaghiF,CondemiAM,CoronaA.Predictors of prolonged mechanical ventilation in a cohort of 3,269 CABG patients. Minerva Anestesiol. 2007;73:615-21.

7. Natarajan A, Samadian S, Clark S. Coronary artery by pass surgery in elderly people. Postgrad Med Journal. 2007;83:154-15.

8. Sharma G, Goodwin J. Effects of aging on respiratory system physiology and immunology. Clinical Interventions in Aging. 2006;1(3):253-60.

9. Blasberg JD, Schwartz GS, Balaram SK. The role of gender in coronary surgery. Eur J Cardiothorac Surg. 2011;40:715-21.

10. Konstam MA, Abboud FM. Eection Fraction: misunderstood and overrated (changing the paradigm in categorizing heart failure). Circulation. 2017;135:717-9.

11. Capdeville M, Lee JH, Taylor AL. Effect of gender on fast-rack recovery after coronary artery bypass surgery. J Cardiothorac Vasc Anesth. 2001;2(15):146-51.

12. Steidl S. The Adverse Effects of the Cardiopulmonary Bypass Machine. Liberty University. 2011;1-35.

13. Grocott HP, Smith MS, Mangano CT. Cardiopulmonary Bypass management and Organ Protection. Dalam: Kaplan JA, Reich D, Savino JS, penyunting. Kaplan's Cardiac Anesthesia. Edisi ke-6. Missouri: Elsevier Saunders; 2011. hlm. 862-4.

14. Rodrigues CD, Oliveira RA, Soares OM, Figueiredo LC, Sebastião Araújo, Dragosavac D. Lung injury and mechanical ventilation in cardiac surgery: a review. Rev Bras Cir Cardiov. 2010;22(4):375-83.

15. McLellan SA, Walsh TS. Osygen delivery and haemoglobin. $\mathrm{Br} \mathrm{J}$ Anaesth. 2004;4(4):123-6.

16. Hébert PC, Blajchman MA, Cook DJ, Yetisir E, Wells G, Marshall J, dkk Do blood transfusions improve outcome 
related to mechanical ventilation? CHEST. 2001;119:1850-7.

17. Hébert PC, Tinmouth A, Corwin HL. Controversies in RBC transfusion in the critically ill. CHEST. 2007;131:1583-90.

18. Ji Q, Chi L, Mei Y, Wang X, Feng J, Cai J, dkk. Risk factors for late extubation after coronary artery bypass grafting. Heart and Lung. 2010;4(39):275-82.

19. Ji Q, Duan Q, Wang X, Cai J, Zhou Y, Feng J, dkk. Risk factors for ventilator dependency following coronary artery bypass grafting.
Int J. Med. Sci. 2012;9(4):306-10.

20. Rezaianzadeh A, Maghsoudi B, Tabatabaee H, Keshavarzi S, Bagheri Z, Sajedianfard J. Factors associated with extubation time in coronary artery bypass grafting patients. Peer J. 2015:1-11

21. Rajaei S, Dabbagh A. Risk factors for postoperative respiratory mortality and morbidity in patients undergoing coronary artery bypass grafting. Anesth Pain. 2012;2(2):60-5. 